\title{
Habitat Potential Model and Efforts to Reduce Risk of Animal Accidents in Arterial Road Between Wangon - Kebasen
}

\author{
Sakinah Fathrunnadi Shalihati \\ Pendidikan Geografi Universitas Muhammadiyah Purwokerto \\ e-mail: queen.geo85@gmail.com
}

\begin{abstract}
The purpose of this study is to determine the potential habitat for each species based on land use and reducing the risk of accidents animals with recommendation traffic signs "Wild Animal Crossing" on the distribution of potential habitat. Qualitative descriptive method was used. The unit of analysis is the villages along the arterial road between Wangon to Kebasen Banyumas. The results show that the potential of the habitat of each species differences, the most widely spread of potential habitat is the narrowest rats and cats and dogs are for the location of this study, and the recommendations of the traffic signs can be placed around the adjacent street or entering potential wildlife habitat with moderate and high classification.
\end{abstract}

Keywords: habitat, wildlife, road, accident

\begin{abstract}
Abstrak
Tujuan penelitian ini untuk mengetahui potensi habitat tiap jenis satwa berdasarkan penggunaan lahan dan upaya mengurangi resiko kecelakaan satwa dengan rekomendasi rambu lalu lintas "Hati-Hati Banyak Satwa" pada persebaran potensi habitat satwa. Metode penelitian diskripsi kualitatif, unit analisisnya adalah desa-desa di sepanjang jalan arteri antara Wangon hingga Kebasen Kabupaten Banyumas. Hasil Penelitian menunjukkan potensi habitat tiap jenis satwa yang perbedaan, paling luas persebaran potensi habitat adalah tikus dan tersempit adalah kucing dan anjing untuk lokasi penelitian ini, dan rekomendasi rambu lalu lintas tersebut dapat ditempatkan disekitar jalan yang berdekatan atau memasuki potensi habitat satwa dengan klasifikasi sedang dan tinggi.
\end{abstract}

Kata kunci: habitat, satwa, jalan, kecelakaan

\section{Introduction}

Biodiversity, both for flora and fauna, is considered as one of food chain balances in the world. Flora and fauna are important since they can not be separated from human's life and that relationship is described in a food chain which results in a transformation of physics and energy. Nevertheless, in this recent era technology transformation has a susceptability in several parts of the food chain due to the climate change. Furthermore, it is not only the climate change but also other factors particularly human activities which may cause the susceptability.

Human activities are vary in any aspects such as agriculture, education, trade, industry, telecomunication, transportation, and others and these certainly give significant advantages and values in their lives. On the contrary, flora and fauna may experience disanvatages when they become parts of human activities with no environmental knowledge. One of the activities which needs to be concerned is transportation. The transportation design, the fuel which supports pollution and the people who drive cars or ride motorcycle with less concern about animals existence around the street are several examples of this activity.

There are only few researches about animal accidents on roads in Indonesia; meanwhile, Brazil begins to show their concern about it. The number of animal's deaths due to road acccident is high that is not less than 475 millions and the animals killed in the accidents mostly are small animals such as frogs and snakes which hold an important role in food chain and pest control. By exploring the information from the people to identify the areas prone to accidents and taking a picture of the victims and location to classify types of accident based on the animals such as amphibis, reptiles, mammals or aves, Brazil government is expected to make a map of areas prone to accident easily. Afterwards, those data will be useful for the government to arrange a guidance to build a better and safer roads (Maskur, 2014).

Rules about roads in Indonesia are regulated in UU 
RI No 38 year 2004 and PP RI No 34 year 2006 which explain about roads mainly due to their functions which are classified into artery, colector, local and neighbohood roads. Artery roads are roads which vehicles may go in high speed. Based on the research on the artery roads between Wangon District and Kebasen District, there are several killed animals due to road accident. Steepness level of these roads is 8$15 \%$ so that it is relatively easy for the animals to move from one place to another without any relief distractions.

Animals in this research mainly are mammals, aves, amphibies and reptiles. Rats, cats and dogs are mammals which mostly have road accident and chickens, frogs and snakes, aves, amphibies and reptiles which mostly have it as well. Habitat is a shelter for the animals and a place for reproduction and food hunting. It is also called a place in which flora and fauna live. In this research, habitat uses the land use approach since it is basically a description of land use with the animals mentioned in the research.
This research is significatly needed as our concern to biodiversity and it is expected to open our mind in driving or riding behaviour. Furthermore, it will be a good model for an animal accident research. The goals of this research are to find out the distribution of animal habitat potency in the areas around artery roads and to find any efforts to reduce the animal accident in the level of animal habitat potency by recommending spesific traafic signs for the arterial road between Wangon and Kebasen using Geographic Information System.

\section{Research Method}

Location of this research is an artery road between Wangon and Kebasen districts and some villages around the road which are situated in Banyumas Regency, Central Java Province. Figure 2 shows the map of research location.

This research uses a digital map of Geospatial Information Institution which consists of road layer, land use layer, river layer, administration layer, and a

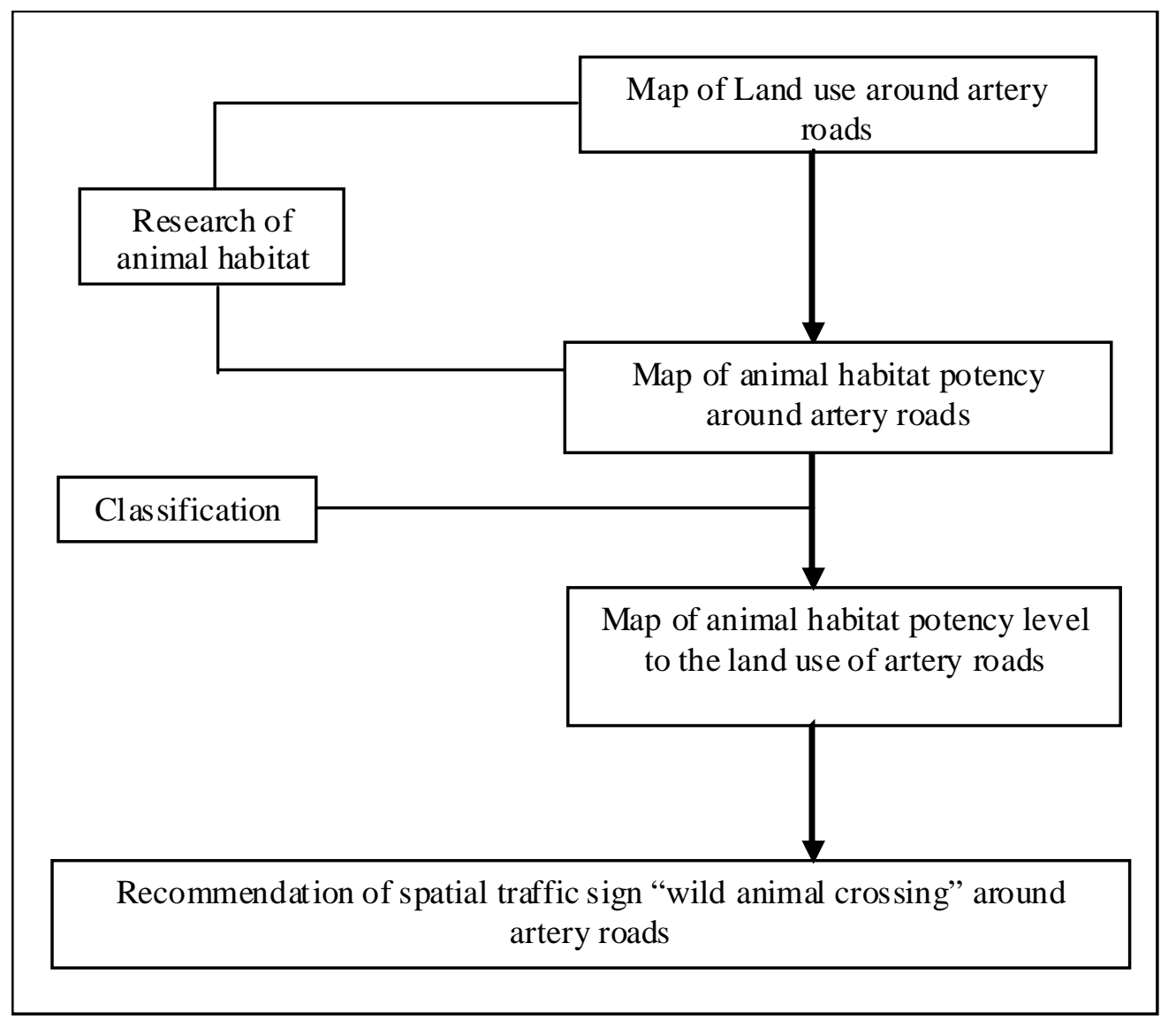

Figure 1. Research Scheme 


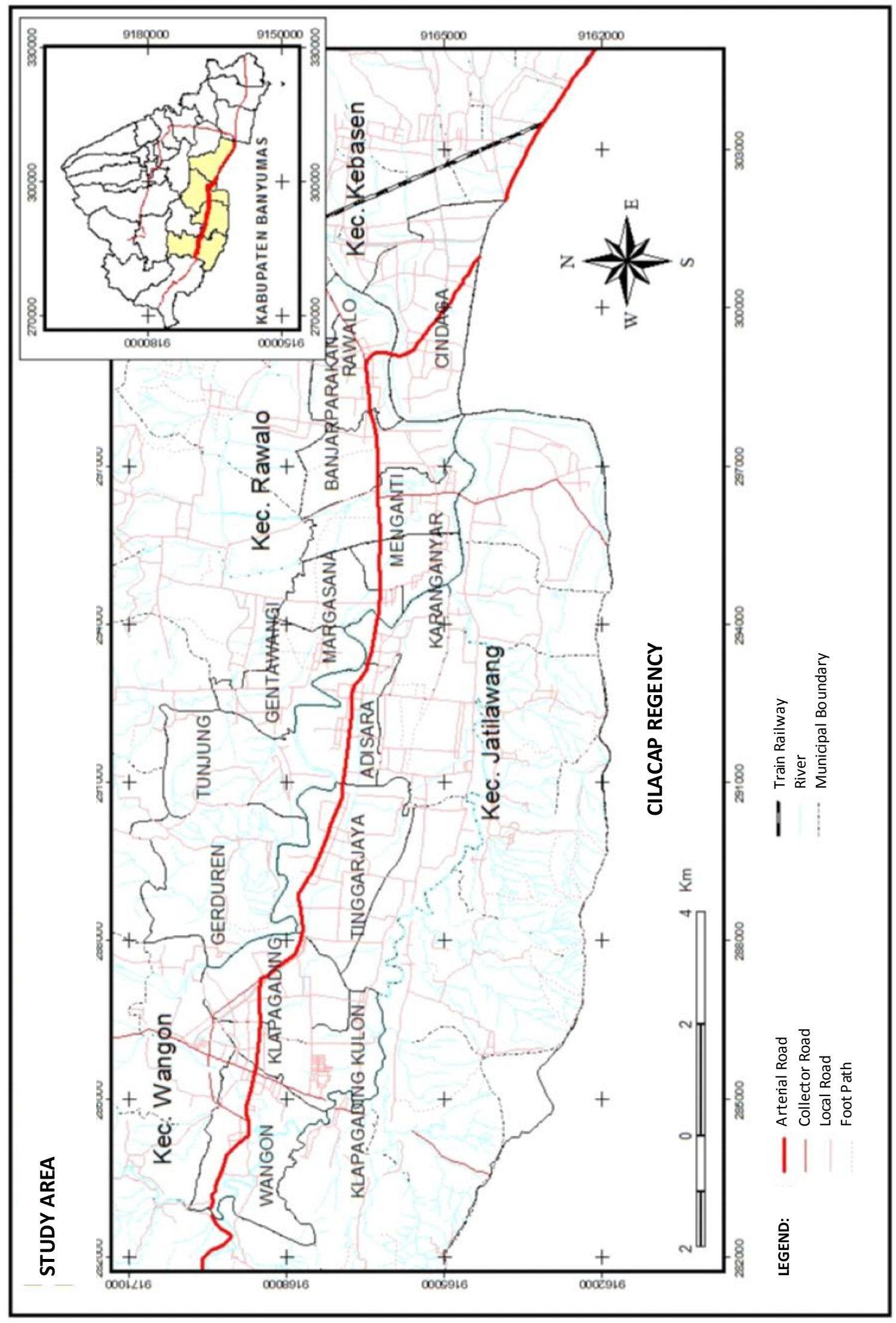

Figure 2. Admistration map of villages around artery road between Wango and Kebasen 
Table 1. Animal Habitat Potency to the land use in artery road between Wangon and Kebasen

\begin{tabular}{|c|c|c|c|c|c|c|}
\hline \multirow[t]{2}{*}{ No. } & \multirow[t]{2}{*}{ Type } & \multirow[t]{2}{*}{ Animal } & \multicolumn{4}{|c|}{ Landuse } \\
\hline & & & Fresh water & Bush & Bulding & Farmland \\
\hline \multirow[t]{3}{*}{1.} & Mammal & Rats & & $\mathrm{v}$ & $\mathrm{V}$ & $\mathrm{V}$ \\
\hline & & Cat & & & $\mathrm{v}$ & $\mathrm{v}$ \\
\hline & & Dog & & & $\mathrm{v}$ & $\mathrm{v}$ \\
\hline 2. & Reptile & Snake & $\mathrm{v}$ & $\mathrm{v}$ & & $\mathrm{v}$ \\
\hline 3. & Aves & Chicken & & $\mathrm{v}$ & & $\mathrm{v}$ \\
\hline 4. & Amphibi & Frog & $\mathrm{v}$ & $\mathrm{v}$ & & $\mathrm{v}$ \\
\hline
\end{tabular}

Table 2. Animal Habitat Potency to the land use in artery roads between Wangon - Kebasen

\begin{tabular}{lllcccc}
\hline No. & Type & Animal & \multicolumn{4}{c}{ Land use } \\
\cline { 3 - 6 } & & & Residence & Grass & Ricefield & Field \\
\hline 1. & Mammal & Rats & $\mathrm{v}$ & & $\mathrm{v}$ & \\
& & Cat & $\mathrm{v}$ & & & \\
& & Dog & $\mathrm{v}$ & & & \\
2. & Reptile & Snake & & & $\mathrm{v}$ & $\mathrm{v}$ \\
3. & Aves & Chicken & $\mathrm{v}$ & $\mathrm{v}$ & & $\mathrm{v}$ \\
4. & Amphibi & Frog & & & $\mathrm{v}$ & \\
\hline
\end{tabular}

computer set with its software ArcView 3.3 for spatial data process which is completed by habital potential data in land use as the result a study.

Method of this research is descriptif qualitatif in which it explains the relationship of any information in data usage. The map that is used is the map of land use, the map habitat potency of every type of animals including rats, cats, dogs, snakes, chickens, frogs and the map of habitat potential level in several villages around artery road between Wangon and Kebasen.

Data analysis using geographical information system in this research will explain an illustration of data connection and the spatial analysis will describe the pattern of land use distribution in several villages around artery road between Wangon and Kebasen. Meanwhile, the way to determine habitat potency for each animal should be supported by any information about habitat potency data of it as shown in Table 1 .

The table is a study result to determine the research location and it may have different approaches for the same or diferent locations. Moreover, classification of animal habitat potency is determined in different way as well that there are low, medium and high classification which use spatial analysis for the result.

\section{Result and Discussion}

\section{Habitat of each animal based on the land use}

The land utilizations around artery road between Wangon and Kebasen are vary: fresh water, bush, building, garden, residences, grass, ricefield and field. The ricefield is the largest that its percentage approximately $68 \%$ or $10,003.8$ from the total area $14,733.5$ ha. Figure 3 shows the land utilization of villages around artery road between Wangon and Kebasen.

Animals have an ability and a characteristic to adapt themselves in their habitat. The result of the habitat potency analysis of the animal in the land use around artery road between Wangon and Kebasen shows a habitat distribution pattern of different animals. Mammals as one of the animal types have different pattern and rats have a larger habitat potency pattern compared to cats and dogs due to their capability to adapt in moist or dry areas. Figure 4 shows the distribution map of rat habitat potency. Rat distribution is wide since the location of the research is dominated by farmlands in which food stock is abundant. Furthermore, residences, building, garden, bush are places that rats like due to their food stock. 


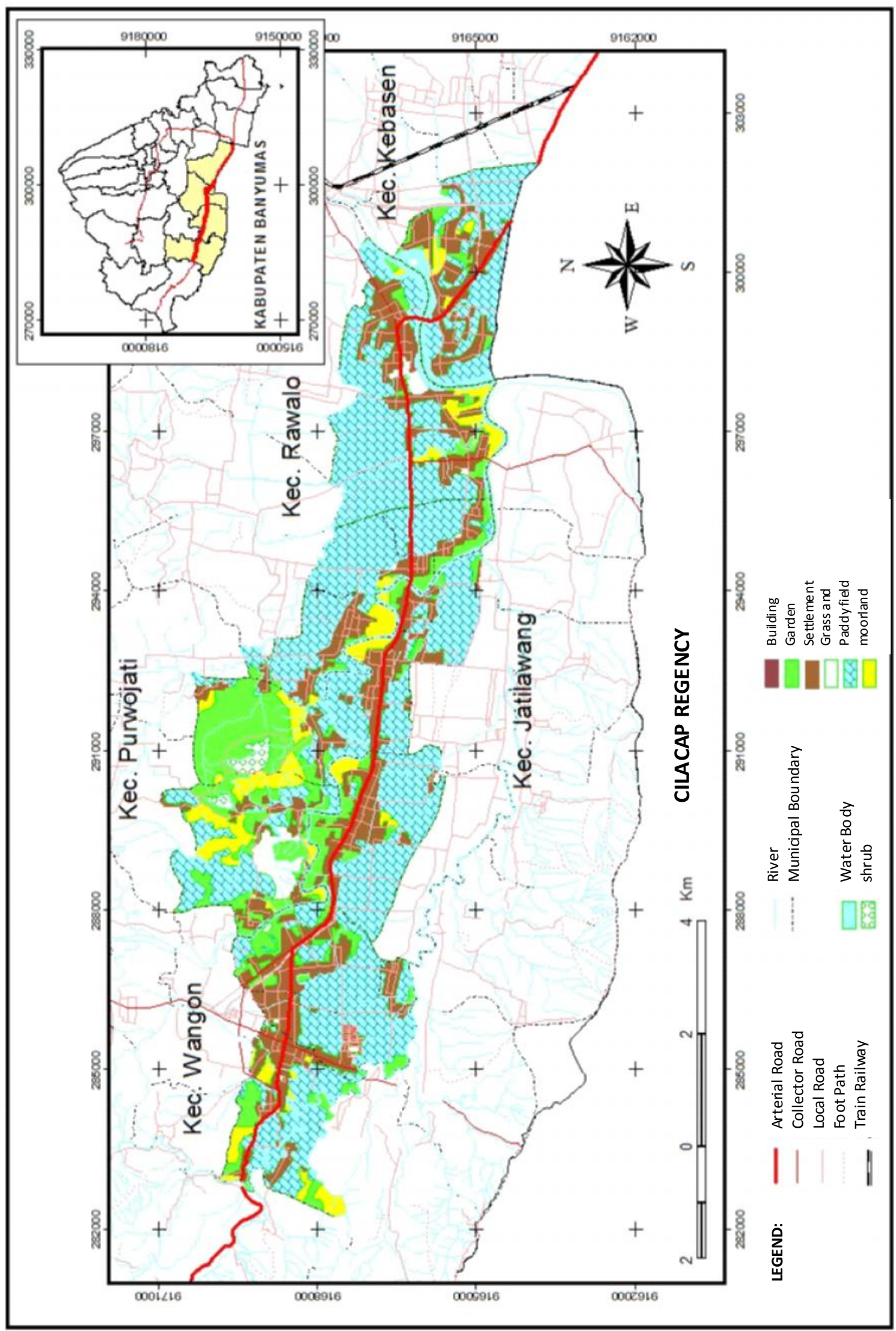

Figure 3. Map of landuse in villages around artery road between Wangon and Kebasen 


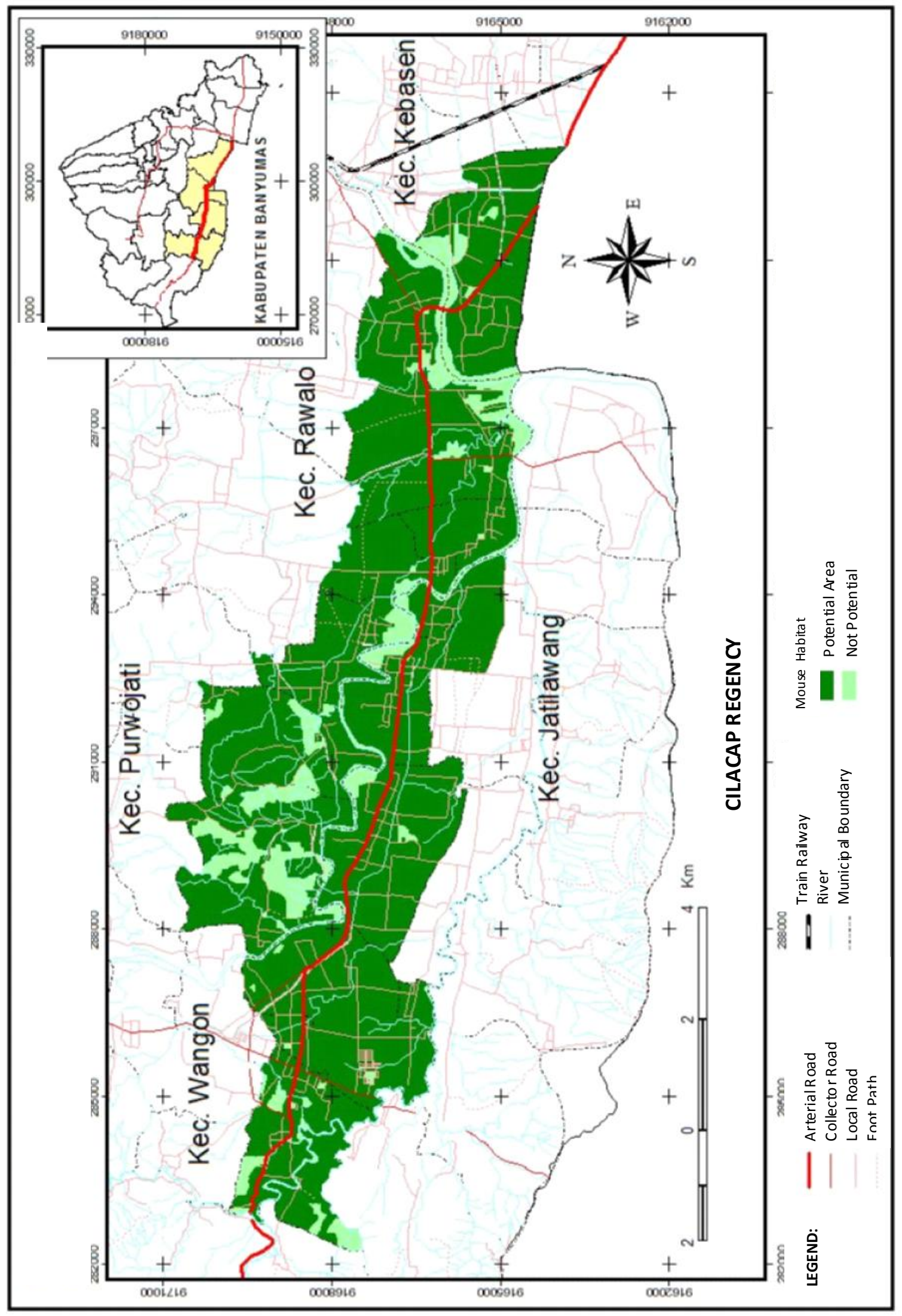

Figure 4. Distribution map of Mouse habitat potency in villages around Artery road between Wangon and Kebasen 


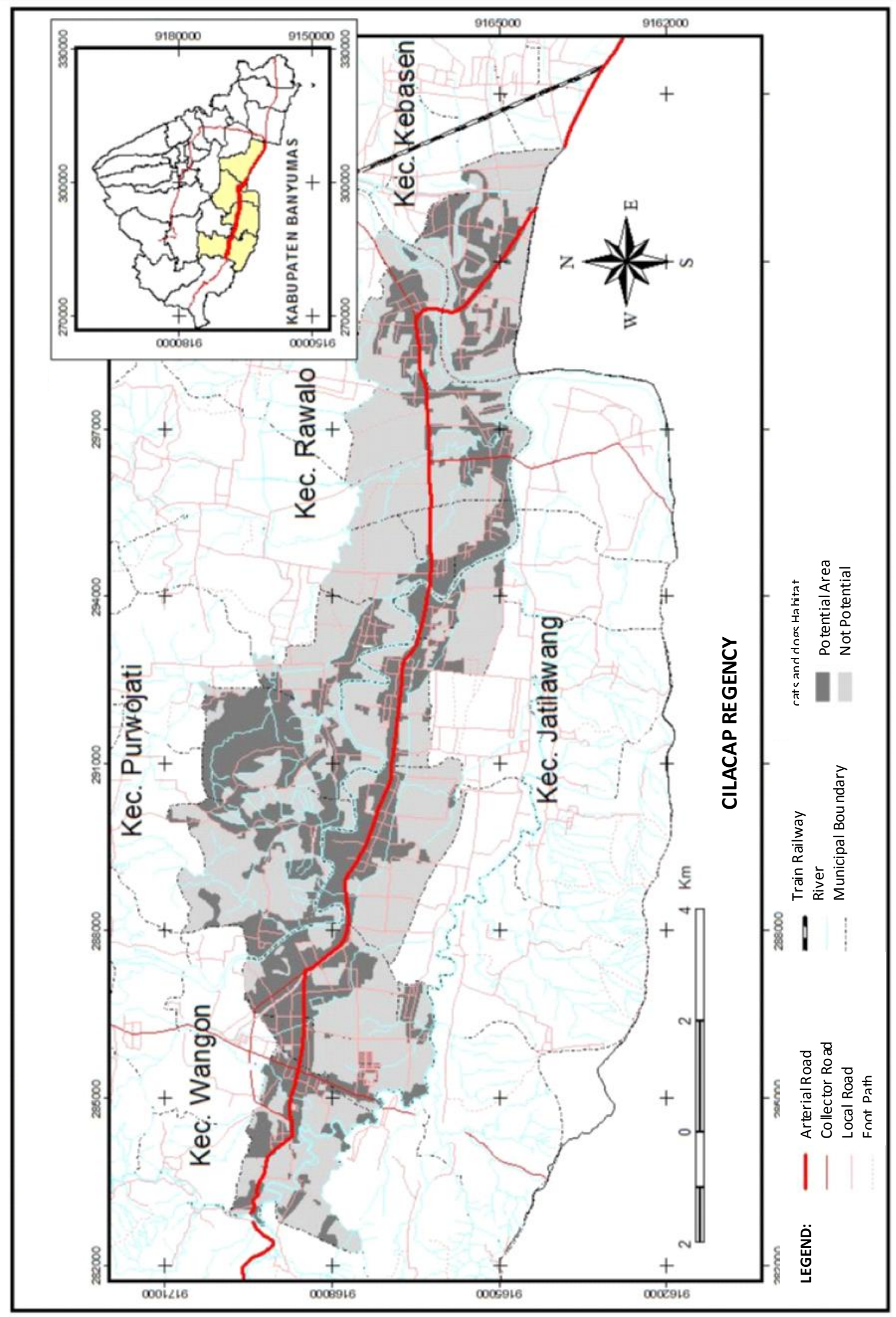

Figure 5. Distribution map of Habitat Potency of cats and dogs in villages around artery roads between Wangon-Kebasen 


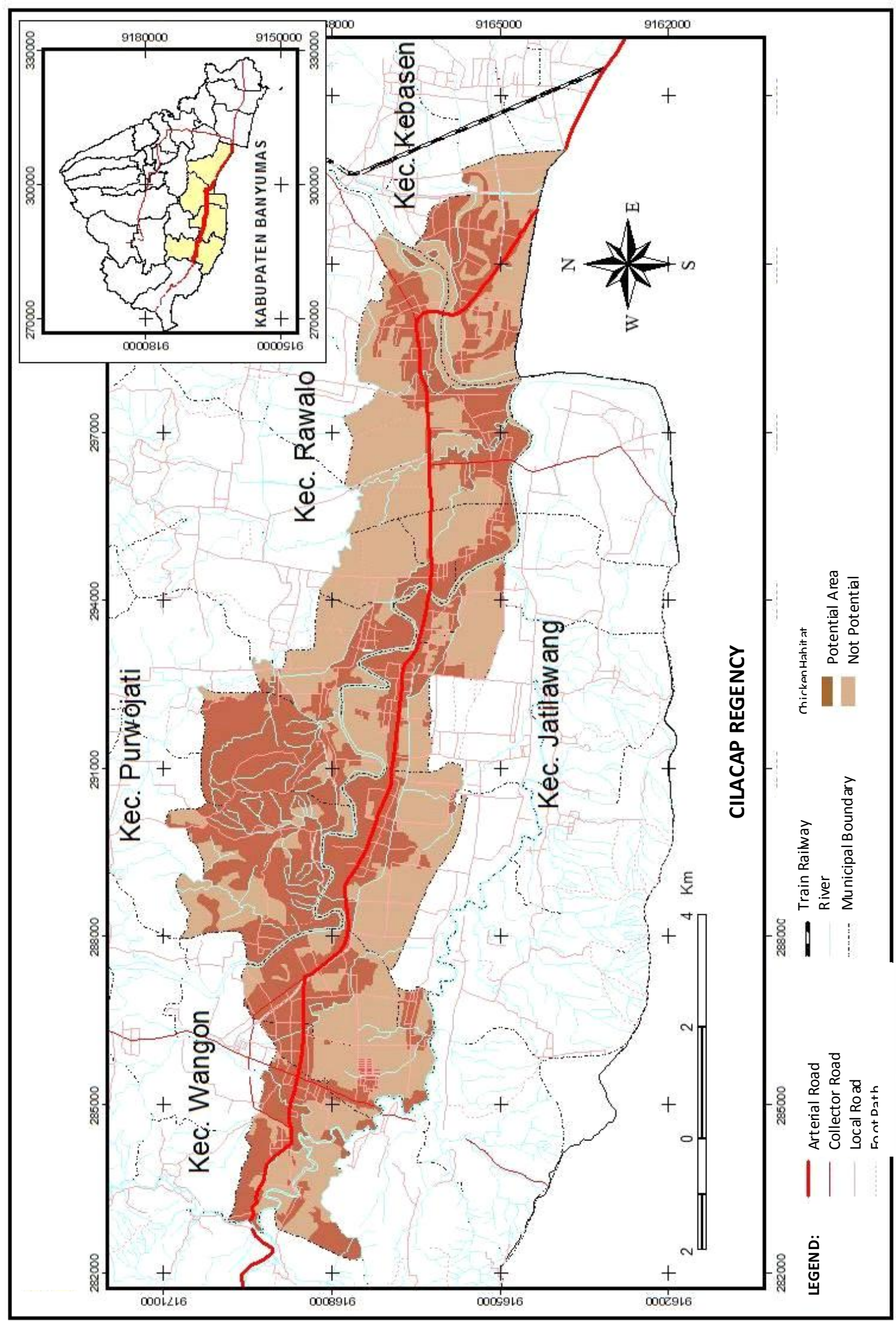

Figure 6. Distribution map of chicken habitat potency in vallges around artery road between Wangon and Kebasen 


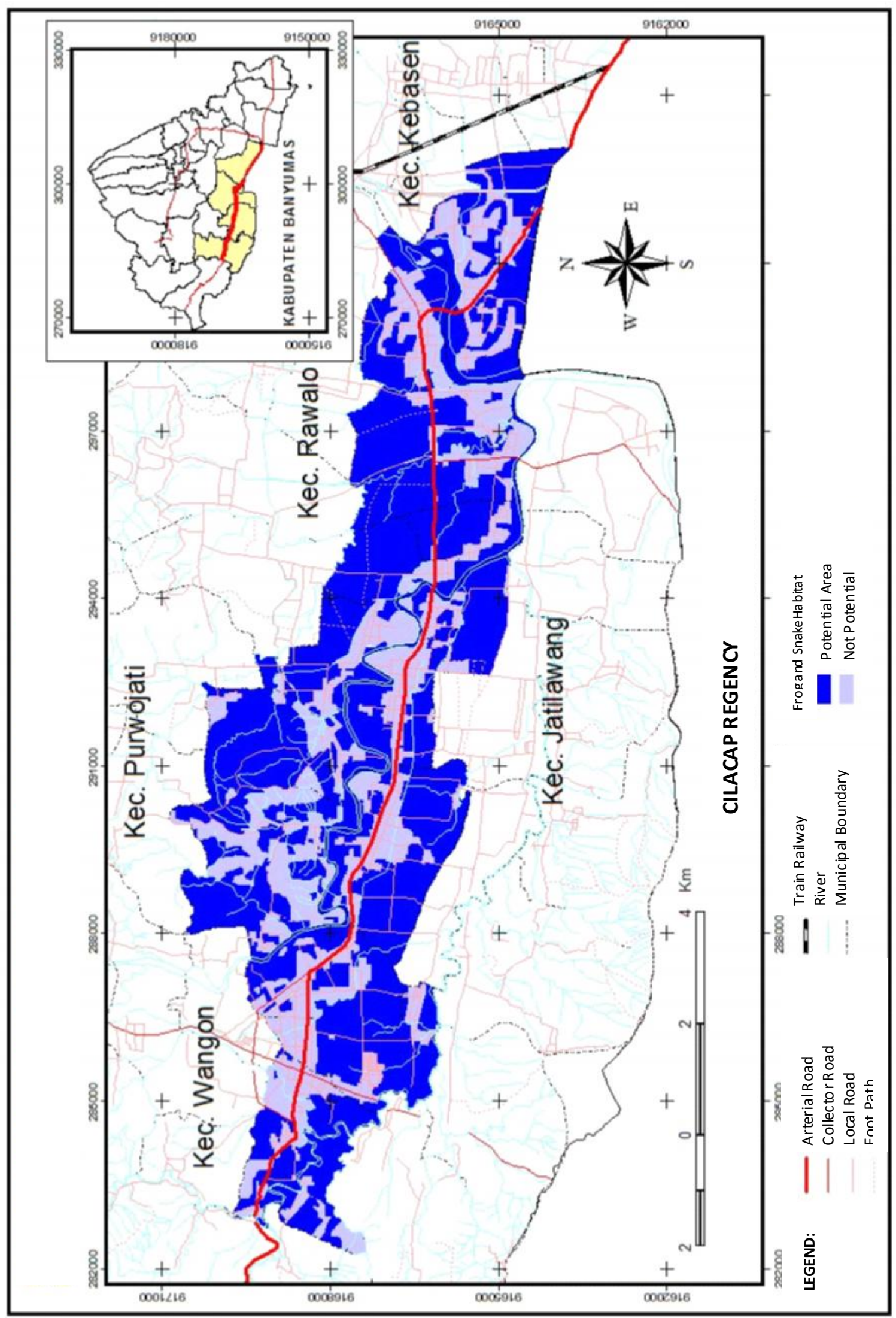

Figure 7. Distribution map of Frog and Snake habitat potency in villages around artery road between Wangon and Kebasen 


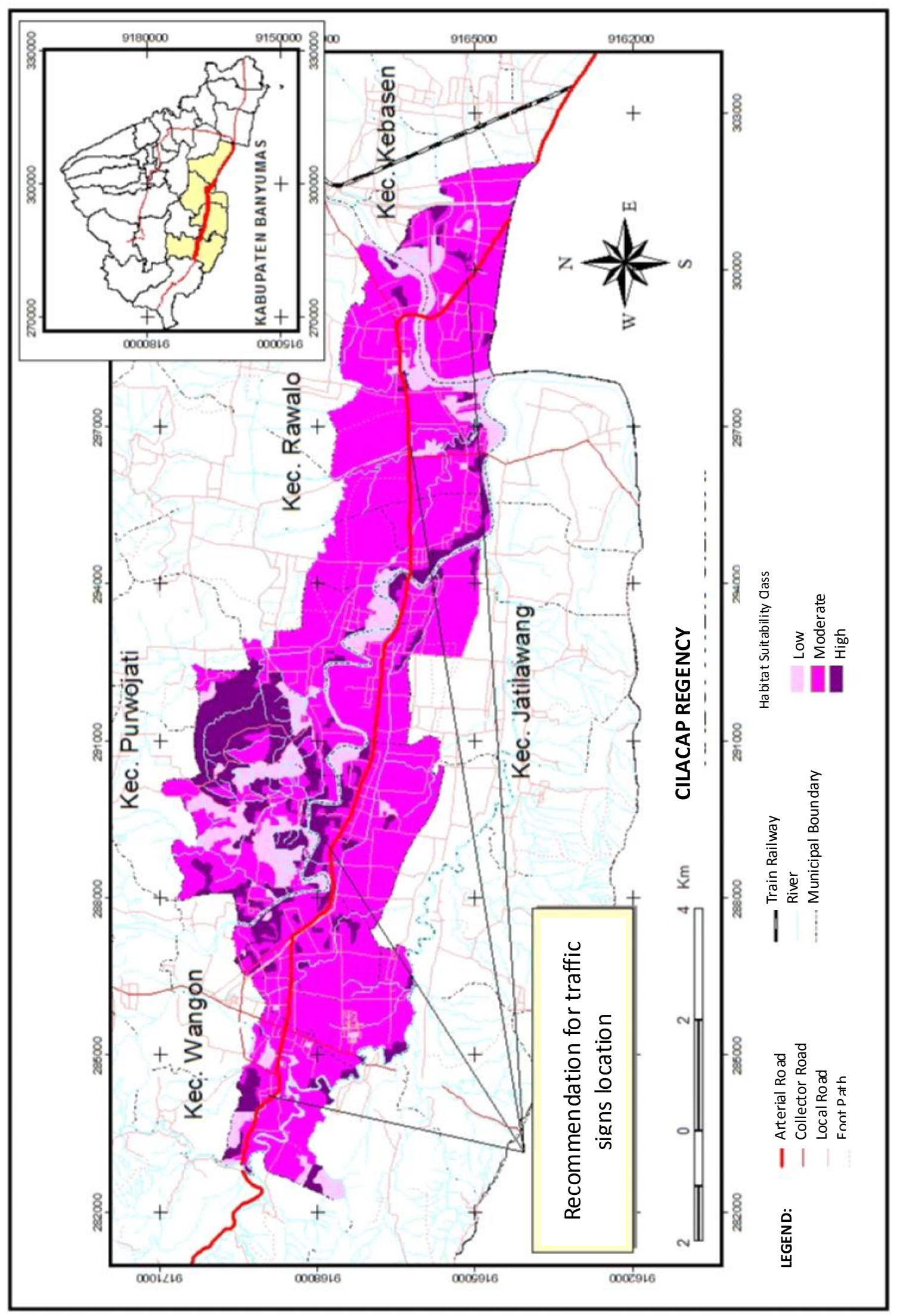

Figure 8. Recommendation map of traffic signs based on distribution of animal habitat potency in villages around artery road between Wangon and Kebasen 
Meanwhile, Figure 5 shows the distribution map pf cat and dog habitat potency based on land use. Its distribution is more restricted than rat distribution since cats and dogs' charactereristic that they don't like moist places. They prefer staying in areas with abundant food stock such as residences, buildings and dry farmlands. People have cats as pets and predators of rats while they have dogs as guards of farms, fields, buildings and pets as well. These kinds of animals, cats and dogs, are vulnerable of road accidents due to their natural characteristic to search or hunt for food.

Chicken as one of the most used aves in the world from its egg, meat, feather till its bones with its quick regeneration, tame character and mainly its small habitat, makes people like to breed it as their food stock. Therefore, chickens roam everywhere in any kind of places to hunt for food and some of the use or cross the artery roads which causes accidents. Figure 6 shows the distribution of chicken habitat potency in villages around artery road between Wangon and Kebasen. It describes that the habitat of chicken is wider than the habitat of cat and dog, bit is is not as wide as the habitat of rats. Chicken habitat covers bush, field, and garden whereas inundated areas like tunnels, ponds and ricefields are not their habitat.

Snakes and Frogs have something in common in this research based on the land use in research area. Both like areas with water like inundated areas, ponds, tunnels, irrigation cannals, rice fields and even places with no human's activities. Figure 7 give particular information about the distribution of frog and snake habitat potency in villages around artery road around Wangon and Kebasen. Frogs frequently become victims of accident since they jump too far into the artery roads due to their predators those are snakes.

\section{Classification of Animal Habitat Potency and Reccomendation of Traffic Sign "Animal Passing”}

Based on the explanation above, fields are dominantly used by animals as habitat potency. Moreover, they have the highest animal biodiversity based on other areas. The bush and residents are areas which have 4 kinds of animal habitats, while building and ricefield have 2 , and grass and soil have 1 animal habitat. The number of animals in the areas may become a value for habitat potency classification. Meanwhile, the high and medium level of habitat potency classification of the artery roads around the areas may become a recomendation for having traffic sign "Animal Passing" as has been spatially informed by Figure 8 .

\section{Conclusion}

1. There are multiple functions of land use around us, those are as residents and as habitat of flora and fauna. Both of them are very significant and unseparatable in food chain and human life.

2. This research is still not perfect since it is just a model of another researches about animal existence around the location and it has no validity test so that for the next researches based on this research, it is highly recommended to have a trial for the result. Residents' information about the animal accidents should be a high consideration as well.

\section{Acknowledgement}

Let me deliver my gratitude to my collegues in Geography Department, Faculty of Education, Muhammadiyah University in Purwokerto for any supports in writing this research.

\section{References}

Darmawan, Boby. (2008). Keanekaragaman Amfibi di Berbagai Tipe Habitat: Studi Kasus di Eks-HPH PT Rimba Karya Indah Kabupaten Bungo Provinsi Jambi. Skripsi. Institut Pertanian Bogor. Departemen Konservasi Sumberdaya Hutandan Ekowisata Fakultas Kehutanan.

Ewnawati, Dwi dan Dwi Priyono. (2013). Pola Sebaran Spesies Tikus Habitat Pasar Berdasarkan Jenis Komoditas di Pasar Kota Banjarnegara. BALABA Vol.9, No.02. Halaman 58-62.

Hatmosrojo, R. Dan Budiana, N.S. (2008). Melatih Anjing Penjaga. Penebar Swadaya: Jakarta.

Maskur, Fatkhul. (2014). Tekan Kematian Satwa, Ekologis Brasil Kembangkan Aplikasi Urubu, [online], dari http://m.bisnis.com [ 22 Oktober 2014].

Purbatrapsila, Azhari. (2009). Studi Keanekaragaman Jenis dan Sebaran Spasial Ular Pada Beberapa Tipe 
Habitat di Taman Nasional Tanjung Puting, Kalimantan Tengah. Skripsi. Institut Pertanian Bogor. Departemen Konservasi Sumberdaya Hutandan Ekowisata Fakultas Kehutanan.

Subagyo, Agus et al. (2013). Survei dan Monitoring Kucing Liar (Carnivora:Felidae) di Taman Nasional Way Kambas Lampung Indonesia. Seminar Nasional Sains dan Teknologi V. Lembaga Penelitian Universitas Lampung. 